\title{
The regulative lock-in: The challenge of establishing Sami fisheries governance in Norway
}

Jahn Petter Johnsen, Norwegian College of Fishery Science, University of Troms $\varnothing$ - The Arctic University of Norway, (corresponding author). E-mail: Jahn.Johnsen@uit.no Siri Ulfsdatter Søreng, School of Business and Economics, University of Troms $\varnothing$ - The Arctic University of Norway, E-mail: Siriulfsdatter@hotmail.com

\section{Acknowledgement}

The authors thank the two anonymous reviewers and Maarten Bavinck for useful comments. Thanks to Proof-Reading Service (www.proof-reafing-service.com) for thorough editing and proof reading.

\section{Funding}

This article is funded by the Norwegian College of Fishery Science and the authors.

\section{Authors' contributions}

The authors have contributed equally to the article. Both authors have critically reviewed text written by the other and have contributed to writing and editing all parts of the document. Both authors agree with the analysis and conclusion.

\section{Competing interests}

The authors declare that they have no competing interests. 


\section{Abstract}

For almost 30 years, the Sami Parliament has worked to gain influence in the Norwegian fisheries governing system in order to secure Sami fisheries as the material basis of Sami culture. Due to developments in international law and their implementation in state law, the Sami Parliament has gained formal access to the country's fisheries governance decision-making process. This paper addresses the challenges for a Sami fisheries approach to gain influence in the national governance system. A major issue relates to differences between the institutional design of the Norwegian system, with ecosystem health, profitability and individual welfare as main concerns, while important pillars formulated by the Sami Parliament are subsidiarity and collective rights. In this article, we discuss what might be the way forward for a Sami fisheries policy to expand within the Norwegian fisheries governance system.

Keywords: fisheries governance, Norway, Sami, fishing rights, institutional analysis

\section{Introduction}

Fishing, together with reindeer husbandry, are the most important forms of traditional Sami livelihood; they constitute the material basis for Sami culture, Sami settlements and Sami language. The historically harsh, state-driven assimilation of the Sami in Norway has especially put its footprint on the Sea Sami population (Minde 2005). Coastal Sami's identity changed from being at the frontstage to the backstage (Eidheim 1971; Paine 1957, 1965), as consequence that Sami on the coast almost disappeared as a category in the official registers. Today's revitalisation of Sami culture and identity has led to people being aware of and recognising their 'Saminess' (Pedersen et al. 2012); in addition, more Sami are enrolling in the Sami Parliament's electoral register. ${ }^{1}$

As a political actor, the Sami Parliament seeks to influence the Norwegian fisheries governance system by breaking in a different approach to fisheries management (Jentoft and Søreng 2017; Josefsen 2014). This approach stresses Sami fishers' rights as a collective and not as individual fishers, as opposed to the Norwegian fisheries system. The Norwegian fisheries governance system is a result of an incremental development from an open access system into a closed system with permits and partly transferable individual vessel quotas. Despite this transferability, which in fact is not clearly legally defined and therefore disputed, the preamble of the Marine Resources Act points out that fish resources are the people's common property and that no individuals can have perpetual property

\footnotetext{
${ }^{1}$ The Norwegian Sami Parliament (established 1989) is the main political institution for strengthening the Sami's political, social and cultural position. It is a democratically elected body comprised of 39 representatives elected every four years. Only those who chose to register in the Sami Electoral Register have the right to vote. About 17,000 persons are listed in the electoral register, which is the only official register of Sami in Norway. From September 2017 to February 2018 about 600 new persons enrolled. Source: https://www.nrk.no/finnmark/-eg-kan-ikkje-spraket_men-eg-er-samisk-1.13900895, https://www.sametinget.no/Valg/Valgmanntall, accessed 28 February 2018)
} 
rights to the resources (NOU 2005:10, Proposition to the Parliament 2007-2008). Formally, commercial fishing permits and licenses are issued by government authorities and grant permission to fish only under specified conditions. The Norwegian system is characterised by path dependencies, broad political compromises in the national Parliament and corporative compromises between the fisheries authorities and the largest stakeholder organisation, the Norwegian Fishermen's Association (NFA), (Hoel, Jentoft and Mikalsen 1996). Hence, the system is rather complicated and technical, but also heavily institutionalised around the compromised solutions (see Johnsen 2014; Johnsen and Jentoft 2018). Consequently, it is difficult to introduce, or 'break', new solutions into the system. Leaning on document and literature studies - and drawing on years of field research (Jentoft and Johnsen 2015; Johnsen and Jentoft 2018; Søreng 2007; 2008; 2013, Jentoft and Søreng 2017) - we explore the institutional obstacles to (Sami) fisheries arrangements based on the principle of collective rights, within the framework of a governance system which stresses individual rights. We also discuss what options may exist to realise this kind of institutional reform.

\section{An institutional approach to Norwegian fisheries}

For centuries, fisheries have been a main livelihood for people along the Norwegian coast. In 1938, the Parliament's passage of the Raw Fish Act, gave fishers the right to control first-hand fish sales, and instituted a central pillar for a corporative fisheries governing system in Norway (Holm 1995). The Raw Fish Act concluded a number of processes that started in the 19th century with fishers' involvement in management. Studies of these processes, and the impact on the governing institutions in Norway, have contributed to the development of the concept of co-management in fisheries (Jentoft 1989; Jentoft and Kristoffersen 1989; Jentoft, McCay and Wilson 1998). Since the 1970s, Svein Jentoft has been a central scholar in this field. In many of his studies, he has been inspired by Scott (1995) who proposed the Normative, Cognitive and Regulative pillars of fisheries institutions. The first concerns norms and social values, the second involves processes of communication and learning and the third is about the regulative framework, rules and regulations. All three pillars are interactive, affecting each other. However, robust institutions will always resist radical change, and in democratic institutions, change will have to follow certain procedures and be affected by power relations. Moreover, the inclusion of stakeholder interests makes change a complex issue. According to Ostrom (1990), institutions with strong pillars and high legitimacy that actually work, will be robust. Therefore, slow reforms are more likely to occur than radical changes, except when new situations, like for example a resource crisis, arise. 
Svein Jentoft's work $(2000,2004,2006)$ places particular emphasis on the normative dimension in terms of morals and values that are guiding fisheries management and on knowledge and learning when fisheries management institutions change. For instance, by exploring the 'meta order' of governance, basic values, norms and principles are in focus (Kooiman and Jentoft 2009). In this article, however, we focus on 'first order governing', namely the practical arrangements to regulate the fishers' behaviour, (Kooiman et al. 2005) by shedding light on some of the problems that Davis and Jentoft (2001) and Jentoft and Brattland (2011) identify as a resistance towards change in the governing institutions. The resistance can be understood as a consequence of the norms and cognitive elements that already are built-in, or locked-in, to the present regulatory solutions. Hence, we can understand why the attempts to get acceptance for special and historic Sami fishing rights have failed, while territorial rights have been accepted.

This article explores how path dependencies and institutional lock-ins can be changed in Norway. We discuss why some paths towards change are impossible, while others are not. Similar to Nielsen and Holm (2008), we see path dependency as a result of the choice of a particular solution that becomes locked into a certain pattern of action and where institutions are largely shaped along the lines of existing ones (Jentoft and Mikalsen 2014). For example, it may be difficult to make decisions and to implement changes that have comprehensive legal implications. Existing solutions may be locked into people's perceptions of justice and order (Selznick 2003; Søreng 2007). The lock-ins can create contingency or continuity, and become manifest in form of rules and laws, organisational procedures, infrastructures, agreements, traditions and perceptions. As we will see, there are quite a few of them in the Norwegian fisheries governing system.

\section{Path dependency in the governing of Norwegian fisheries}

\subsection{From fisher welfare to ecosystem health and profitable enterprises}

Although the Norwegian fisheries governing system is filled with path dependencies and lock-ins, it has also undergone reorganisation because of ecological changes. In Norway, where a high number of fishers compete for access to limited fishing grounds during intense seasonal fisheries, spatial regulations have a long tradition. The most prominent spatial management system has been in the North Norwegian cod fisheries, and particularly in the big Lofoten cod fishery. Here the fishing area can be quite crowded and rules for behaviour can be necessary to create order, but with fishers having equal access to fishing grounds as an important principle (Jentoft and Kristoffersen 1989). The long practice of spatial management for regulation of gear use and vessel size is maintained until 
today; as we shall see, it is particularly relevant in relation to Sami fisheries (Johnsen 2017; Jentoft and Søreng 2017).

Before 1990, Norwegian fisheries governance was mainly concerned about fisher welfare and economy. The legal framework encompassed the right to fish for commercial purposes and the control of first-hand sales; it gave only active, registered fishers the right to own fishing vessels. Largely, this framework therefore codified a policy that enhanced the practice of full-time fishing. Related to the increasingly corporative organisation of Norwegian society that developed from the 1930s and continued after the Second World War, a close collaboration between the authorities and the NFA developed (Johnsen 2014). The NFA still organises all types of fishers, from small-scale parttime fishers to owners of larger offshore vessels, and the organisation has meanwhile learned how to negotiate compromises among its members. Hence, the framework and the institutions that grew out of it developed over time into a corporative governance system with shared responsibilities between state and fishers' organisations (Hoel, Jentoft and Mikalsen 1996), with active fishers as the most urgent and legitimate stakeholder group (Buanes et al. 2004; Mitchell et al. 1997).

The legal framework is a typical example of path dependency that, even today, significantly impacts how governance is organised and conducted (Holm 1996; Jentoft 2004). But, with the collapse of the Norwegian Spring-spawning herring stock (Clupea harengus) in the late 1960s, resource concerns came on the agenda in addition to welfare and economy. However, it was first after the collapse in the Arctic cod (Gadus morhua) fisheries in 1989 that resource management became the central issue in Norwegian fisheries policy. As a result, all the important fisheries became quota-regulated on basis of scientific advice from the International Council of the Exploration of the Seas (ICES). In addition, in the coastal fisheries in Norway, which includes small-scale Sami fishers, a strict quota regime was introduced. This move from open access to closed fisheries was a radical shift, with institutional shocks that led to the emergence of new paths for development. While the authorities and the NFA earlier had collaborated about economic support to the fishers, they now shifted to collaborating about resource management.

Following the collapse of the Arctic cod, in 1990, an individual vessel quota (IVQ) system was introduced, in which vessels under 10 meters length received a quota equivalent to the average catches for the last three years preceding the collapse of the Arctic cod fishery. ${ }^{2}$ Vessels under 10 meters that had fished less than the average, which was the case for many of the smallest vessels in the fjords with Sami populations, did not get an IVQ. Rather, the smallest vessels could participate in an Olympic fishery for a part of the total cod quota that was not allocated as IVQs - also known as

\footnotetext{
${ }^{2}$ Vessels longer than 10 meters got a gradual curtailment of their quota according to vessel length down to $50 \%$ for vessels longer than 28 meters. The 1990 allocation were later converted into a system with quota factors (QF) according to vessel length and with the curtailment built into the QF system.
} 
the open group fishery. Since 1990, in principle, there have been very few restrictions for joining the open group, and while the amount of cod that can be fished is limited, in practice, open group vessels have had a free fishery for all other species (e.g. saithe and haddock).

In addition to the IVQ-model, several other models for quota systems were proposed (Reguleringsrådet 1989). Both the NFA and the Coastal Fishermen's Association wanted a quota model that took vessel size and crew size into account. Community or regional quotas were also suggested. However, the authorities introduced IVQs based on vessel length as the only parameter, mainly because of the administrative complexity of the other models. Moreover, other models required new institutional set-ups that broke with the established paths. Parallel to the need for quota regulation, the subsidies that the fisheries had been total dependent of since 1964 were gradually reduced. Therefore, after 1990, securing vessel profitability through overfishing and subsidies became impossible and fishing enterprises were expected to operate with profit within the quota regulations. Still, the arrangements for the smallest vessels rested on certain norms, namely to protect the smallest against the most severe effect of the stock collapse and to maintain flexibility in terms of allowing persons to combine fishing with other incomes (Reguleringsrådet 1989).

Hence, the contemporary Norwegian fisheries governance system is built on three regulative elements. First is a variety of spatial arrangements, set within an IVQ and total quotas (TAC) systems, based on scientific advice from ICES. Second, as a norm, the right to fish should be exclusive for those who have fishing as their livelihood. Finally, it became a requirement to operate with profit (Jentoft and Johnsen 2015; Johnsen 2014; Johnsen and Jentoft 2018; Nielsen and Holm 2008). Thus, in terms of norms and values, after 1990 ecological and economic sustainability can be regarded as the primary objectives of fisheries policy, while the fisheries contribution to maintain employment and community survival are secondary objectives. In addition to these elements, if the NFA is able to negotiate solutions for fisheries regulations or quota allocation, the government generally approves these solutions.

\subsection{A Sami approach to fisheries management - principles of subsidiarity and collective rights}

By means of political influence, a Sami approach to fisheries management has evolved, or found its way, within the Norwegian governance system. The Sami Parliament's Report on fisheries (Sametinget 2004), proposes that those living in a specific area and are dependent on the local natural resources to maintain livelihood, culture and language, should have a first and collective right to use the resources. This would stimulate practical organisational setups, which would secure Sami as an ethnic minority and as an indigenous people in line with national and international law on 
indigenous people (Jentoft and Søreng 2017; Sametinget 2004). ${ }^{3}$ As stressed by Jentoft and Søreng (2017), the above principles take issue with the existing Norwegian governance order, which works from the premise that the fish in the ocean is a common pool resource (Davis and Jentoft 2001; Jentoft 2013). However, as principles of subsidiarity and collective rights do not apply exclusively to Sami fisheries, they may enjoy support from Norwegian small-scale fishers in general (Søreng 2008, 2013). Although policy has been that smaller vessels are allocated shares that correspond to their historic catches (Reguleringsrådet 1989, Ressursfordelingsutvalget 2007), many small-scale fishers in northern Norway felt they were on the losing side of the new policy and argued that the highest quotas seemed to be reserved for the biggest, capital-intensive vessels (Eythórsson 2008).

Due to the introduction of the individual quota regulation in 1990, Sami fishing rights was one of the first cases the Sami Parliament put on the agenda (Angell 2004; Jentoft and Brattland 2011; Søreng 2007). The Sami Parliament argued that Sami fishing practices (small-scale fisheries using simple gears, stationary fisheries close to the shore, and fishing combined with small-scale farming or other activities), were not taken into consideration in the design of the new fisheries policy and had negative consequences for Sami fisheries (Jentoft and Karlsen 1997). The Sami Parliament thus demanded an investigation of the government's legal responsibilities towards Sami fisheries (Davis and Jentoft 2001). According to Davis and Jentoft (2001), this demand took the Norwegian government by surprise; it could not be ignored, and the government had to act on it. The Ministry of Fisheries decided to order an investigation of what kind of legal obligation the government had toward the Sami regarding fisheries management. The report (Smith 1990) concluded, with reference to national and international law, that the Norwegian state had a legal duty to take measures to ensure the survival of Sami fisheries, and that positive discrimination is required to secure the material basis of Sami culture. It concluded that fishing rights should be allocated to the collective of fishers in the traditional coastal Sami settlement area, rather than to individual (Sami) fishers. Smith's (1990) suggestion on how to operationalise collective rights at the level of 'first ordergoverning' (Kooiman et al. 2005) implies a different approach to collective rights than the Sami Parliament's 'meta order' which, in line with international law, stresses the rights of the Sami people (in Norway) as a collective. Smith (1990) suggested that positive discrimination should be arranged on a collective rather than individual basis, arguing that there would be fewer conflicts if privileges were organised along geographical rather than ethnic lines. Setting up this kind of 'first ordergoverning' regulation is not discriminating between Sami and non-Sami fishers within the

\footnotetext{
${ }^{3}$ UN Covenant on Civil and Political Rights, Article 27, secured Sami as an ethnic minority, while the Convention concerning Indigenous and Tribal Peoples in Independent Countries (No. 169), secured the Sami as an indigenous people.
} 
geographical areas the governing solution encompasses, and therefore also acknowledges other coastal people's rights (Norwegian National Human Rights Institution 2016:24, Søreng 2007).

One could argue that a territorial approach to collective rights is reasonable, as small-scale fishing is not solely a traditional Sami occupation but has been a source of subsistence and income for all inhabitants of these northern regions, regardless of ethnicity (Paine 1965; Jentoft 1998). These traditional fisheries, being Sami and non-Sami, were family-organised, seasonal and home-based; however, fishers periodically also participated in fisheries away from home, as for instance the Lofoten fisheries (Jentoft and Kristoffersen 1989). However, the home-based fjord fishery that is combined with several other economic activities is still a more prevalent practice in the traditional Sami area than in other areas along the Norwegian coast (Eythórsson 2008; NOU 2008:5). In today's fisheries, we find these fishers in the open group, as defined in the previous Section. It is this specific pattern of livelihoods that the Sami Parliament strives to protect with their fishery policy. For example, fishers in the Sami area can have higher additional income from sources other than fisheries than fishers in other parts of the country, while still maintaining their status as commercial fishers. Sami fishers who invest in vessels with an IVQ and who undertake full-time fishing have not been the main target for the Sami fisheries policy, even though we see some changes in more recent years (Sametinget 2011).

Although Sami considerations were added to the Norwegian Constitution already in $1988,{ }^{4}$ it was a new situation for the Norwegian government in 1990 to ensure Sami interest in fisheries management. But from 1990, the Ministry of Fisheries has accepted that there was an ethnical dimension in fisheries management (Eythórsson and Mathisen 1998), and it has expressed a will to follow up on Smith's (1990) report (St. meld. nr. 58, 1991-1992). In 1990, following the government's path of directing rights to individual fishers, the Directorate of Fisheries considered the possibility of giving individual Sami fishers special treatment in the quota allocation of cod. Subsequently, the Directorate approached the Sami Parliament and asked to have Sami fishers appointed for this purpose, to which the Sami Parliament responded that such a procedure was both practically impossible and precarious in principle (Eythórsson 1999).

In 1991, applying Smith's (1990) territorial approach to the principle of collective rights, the Sami Parliament proposed Sami fisheries zones that allow for local/regional fisheries management solutions. In 1993, the Ministry of Fishery assembled a committee with members from the government, the fishery, and the Sami Parliament to follow up on the Smith Report, and to examine how the government could incorporate Sami interests in fishery regulations (Fiskeridepartementet

\footnotetext{
${ }^{4}$ Paragraph 108 in the Norwegian Constitution states (authors' translation): "It is the responsibility of the authorities of the State to create conditions enabling the Sami people to preserve and develop their language, culture and way of life."
} 
2003). The committee advised the government in 1997, in line with Smith's territorial approach, to use geographical zonation ${ }^{5}$ to meet Sami fishery interests, instead of implementing measures at an individual level. The committee's majority did, however, reject the Sami Parliament's proposal to establish Sami fisheries zones. The Ministry of Fishery considered that the best way to oblige Sami interests was through the general fishery regulations, but when special measures were considered necessary, these were directed at areas with Sami settlements or at groups of fishers/vessels where Sami fishers are particularly present (Fiskeridepartementet 2003).

In the mid-2000s the Norwegian Parliament, with pressure from the Sami Parliament, initiated a new investigation of Sami fisheries rights. This investigation was directed at the northernmost county in Norway (Finnmark), home to most of the country's Sami population, and was a follow up of the Finnmark Act (2005) which recognised Sami land rights in the region. The Coastal Fisheries Committee (CFC) mandate was to clarify 'Sami and others [non-Sami resident's] rights to fish in the sea in Finnmark' (Brattland 2010; Jentoft 2013; Jentoft and Brattland, 2011; Søreng 2013). The CFC concluded that fishers living in Finnmark have a historical right to fish and that the Norwegian government should legally recognise and formally implement this right. The CFC's report (NOU 2008) included a complete fisheries law proposal for Finnmark and also suggested that an autonomous regional co-management body should be established to manage the fisheries in an inshore zone up to four nautical miles from the baseline ${ }^{6}$ in Finnmark. In reference to national and international law, the recommendation stressed the importance of protecting and promoting Sami culture. The Sami Parliament regards the CFC's work (NOU 2008:5) as a follow-up of the Sami Parliament's Report on fisheries (2004) as well as of the Finnmark Act (Sametinget 2011).

\subsection{Implementing Sami rights in Norwegian fisheries law}

Smith's report (1990) contributed to establishing Sami fisheries as a legitimate concept in Norwegian policy. This is reflected in the process of establishing the new Marine Resources Act (MRA) in

\footnotetext{
${ }^{5}$ The suggested geographical zone had the same administrative scope as the 'Sami Development Fund' ("Samisk utviklingsfond" in Norwegian), which includes Finnmark county and parts of Troms County and Nordland County. The Fund has been a permanent arrangement since 1985 (from 1975-1985 it was a temporary arrangement). In 1992, its objective was revised so it also could give economic support to non-Sami habitants within its geographical scope, on condition that activities led to advancing measures of cultural, social and economic importance for the Sami. The Fund's scope has expanded within the three counties along with the growth of the Sami Electoral Register (see footnote 1). The Fund was initially directed at supporting traditional Sami economic activities such as small-scale fisheries, but has become a means for a general economic development in Sami settlement areas (Skålnes and Nygaard 2007).

${ }^{6}$ The baseline is the line of points from which a nation define the breadth of its maritime zones. Normal baselines follow the low water line along the coast. Due to its indented coast, Norway uses straight baselines between appropriate points. See: UN Law of the Sea, http://www.un.org/depts/los/convention_agreements/texts/unclos/part2.htm, (accessed 12 June, 2018).
} 
Norway. ${ }^{7}$ As part of its mandate, the expert committee drafting the bill considered Norwegian obligations to the Sami population. These obligations are discussed both in the MRA report (NOU 2005) and in the Parliament proposition for the MRA (Proposition to the Parliament 2007-2008). The discussion is concluded in the final MRA (Section 7, point g) which promotes: 'ensuring that management measures help to maintain the material basis for Sami culture. ${ }^{8}$ Moreover, after the mandatory hearings and consultations with the Sami Parliament, Section 1-5 of the draft bill that stated that the ownership of the resources belonged to the Norwegian State, was changed to belong to the Norwegian society as a whole. This formulation reflects that it is the people living in Norway that 'own' the resources and not the state. Although this can be regarded as a normative change that strengthens the Sami fisheries position, Section 7 (point g) did not concretise Sami rights in relation to fishing.

The law proposal resulting from investigating fishing rights in Finnmark (NOU 2008) was followed up by a draft resolution in 2012 (Proposition to the Parliament 2011-2012), to which the Norwegian Parliament gave its support. In its preparatory work the Ministry of Fisheries and Coastal Affairs, after having consulted the Ministry of Justice, decided not to support the idea of historical Sami fishing rights. Nor did it agree with the recommendation to create an autonomous co-management institution for Sami fisheries in Finnmark (Jentoft and Søreng 2017). Both these elements conflicted with the existing regulative pillar directed towards individual rights and a uniform governance system that consulted stakeholders but did not delegate decision-making competence. Instead, in 2012 the Norwegian Parliament passed a reformed version of the MRA, revised the Finnmark Act and added a section to the Participation Act. These revisions gave registered fishers living in Finnmark and in some municipalities in Troms and Nordland (counties that are in the Sami Administration Area) a specific right to fish for cod, saithe and haddock with vessels under $11 \mathrm{~m}$. The revisions confirmed the government's position on the Sami rights issue and gave birth to a new advisory institution within the Norwegian fisheries management: The Fjord Fisheries Board (FFB) [Fjordfiskenemnda in Norwegian] (LOV-2012-09-21-66). The FFB aims to strengthen Sami small-scale fisheries and Sami culture in the inshore areas in the three northernmost counties in Norway. It is a part of the Norwegian fisheries governance system, influenced by the Sami Parliament through its right to appoint half of the Board's members.

\footnotetext{
${ }^{7}$ The process of making legislation in Norway is described by the parliament: https://www.stortinget.no/en/InEnglish/About-the-Storting/Legislation/, accessed 19. January 2018.

${ }^{8}$ An English translation of the MRA is available here (accessed 24 May 2018):

https://www.regjeringen.no/globalassets/upload/fkd/vedlegg/diverse/2010/marineresourcesact.pdf
} 


\section{Discussion: developing a pathway for a Sami fisheries approach}

Since 1990, the Sami Parliament has developed a pathway to gain institutional and discursive influence within the Norwegian fisheries governance system, stressing means that are beneficial for small-scale fisheries in Sami areas. Using international law as well as the Consultation Institute ${ }^{9}$ as crowbars, the Sami Parliament has voiced the necessity of securing the material basis for Sami culture, including fisheries, through political means (Søreng 2007). Brattland (2012) calls this development an 'ethnic turn' in Norwegian fisheries governance, while Jentoft and Søreng (2017) describe it as 'breaking in' a Sami approach to Norwegian fisheries governance. This 'breaking in' has provided a path for expanding a Sami approach to fisheries management within the confines of the Norwegian governance system, both at the meta order and at the first order of governance (Kooiman et al. 2005). The Sami Parliament became a formal part of the Norwegian fisheries governance system in 1992 by assuming membership of the Advisory Council (Davis and Jentoft 2001). The Advisory Council (est. 1983) was a corporative advisory body with industry stakeholder members appointed by the Ministry of Fisheries. From 2004, the Sami Parliament also became a permanent member of the Joint Norwegian Russian Fisheries Commission. ${ }^{10}$ Hence, when the Advisory Council was replaced by the open and less powerful hearing meeting in 2006, the Sami Parliament was already institutionalised as a partner in fisheries governance.

In cases where the government allocates special means to ensure Sami fisheries interests, such means are directed at geographical areas with Sami settlements, or to groups of fishers/vessels in which Sami fishers are participating. The Fjord Lines Arrangement (2004), ${ }^{11}$ the additional cod quotas $(2012)^{12}$, the specific territorial fishing rights that are defined in the Fisheries Participation Act (1999) and the FFB (2014) are examples of these means. These arrangements are partly formed through the Consultation Institute (2005), which constitutes the Sami Parliament's right to be consulted on matters of special concern to the Sami population. For example, the FFB's mandate is to

\footnotetext{
${ }^{9}$ The consultation arrangement is not fixed by law, but in May 2018, the Sami Parliament, The Norwegian Reindeer Association (Norske reindriftssamers landsforbund in Norwegian) and the government reached an agreement about a private bill on consultation rules which is planned to be brought before the Norwegian Parliament in June 2018. https://www.regjeringen.no/no/aktuelt/sametingsradet-og-regjeringen-enige-omlovregler-for-konsultasjoner/id2600801/, accessed 29 May 2018; https://www.regjeringen.no/no/tema/urfolkog-minoriteter/samepolitikk/midtspalte/konsultasjonsplikt-i-samiske-saker/id86931/, accessed 11 February 2018.

${ }^{10}$ The JNRFC is the high-level body for management of shared marine resources between Norway and Russia such as the North-East Arctic Cod. The commission sets quotas for the respective stocks and agrees upon binding management measures for both countries. The membership is restricted to official bodies, experts and the most relevant stakeholder groups.

${ }^{11}$ As a main rule, vessels over 15 meters are not allowed to fish within the Fjord lines. This was originally a measure for protection of the coastal cod stock, but it is also protecting fishing grounds used by small-scale fishers from competition by larger vessels.

${ }^{12}$ An additional quantity of cod is allocated to the fishers in the open group in the Sami area to strengthening small-scale fisheries/fjord fishers.
} 
strengthen the management of the fjord fisheries and the small-scale Sami fisheries and Sami coastal communities in particular. This mandate arose from a series of consultations between the Sami Parliament and the Ministry. On the other side, among fishers outside the Sami area, the FFB and the additional cod quotas are controversial. Jentoft and Søreng (2017:269) argue that the FFB is an institutional compromise between Sami rights claims and Norwegian national interests, born in a context of ethno-political strife. The FFB consists of six members, three appointed by the Sami Parliament and three appointed by county administrations in three northernmost counties in Norway, Nordland, Troms and Finnmark. ${ }^{13}$ The Fisheries Directorate hosts the secretariat for the FFB. Even though the FFB constitutes a sort of regional management, its influence is restricted by its lack of decision-making power that the Ministry insists upon, regarding it as an advisory body for the central government (Jentoft and Søreng 2017:275). The Sami Parliament, on the other hand, has stressed that the FFB should be given decision-making power over certain issues such as gear restrictions, allocation of quotas, setting of fjord lines and dispensation of rules that exclude bigger vessels fishing within these lines (Jentoft and Søreng 2017). This is in line with the Sami Parliament's perspective that those who depend on local resources should have the first right to use them - a principle necessary for maintaining Sami culture, industry and language. According to Jentoft and Søreng (2017), the application of this perspective would fundamentally change the working conditions of the FFB. But is this a possible course, within the Norwegian fisheries governance system, where the basic premise is that fish are a common pool resource?

Almost two decades ago, Davis and Jentoft (2001) argued that indigenous people's fisheries rights claims 'have the transformative potential to turn entire fisheries management systems inside out and upside down' (2001:232). Since then, as we have demonstrated, many legal processes have emerged and have been locked into the Norwegian centralised fisheries governance system, which stresses ecological and economic sustainability. In the meantime, the Ministry and the Norwegian Parliament have rejected the idea that the Sami have historical rights to fish in the north (Jentoft 2013; Proposition to the Parliament 2011-2012). This may in part be because the different committees that have investigated the Sami fishing rights issue have argued for rights based on territoriality and livelihood and not on ethnicity, a position that the Sami Parliament has also supported. However, today's Sami Parliament seems not to have given up the struggle for historical rights. In line with Jentoft and Søreng (2017), there is reason to assume that the issue of having historical Sami fishing rights recognised and self-governance implemented will go on (2017:281). For instance, the Norwegian National Human Rights Institution (2016, 2017) has advised the Norwegian Parliament to follow up on a Sami fisheries law. However, having a later legal process in mind, the so-called

\footnotetext{
${ }^{13}$ A regional reform may result in a merging between two of the counties, but will probably not change the setup of the FFB.
} 
Voldstad case in 2013 , one could ask whether this is a path worth following to increase its influence on fisheries management? In the Voldstad case, the High Court sentence supported the principle that fish resources are a common pool, owned by the people, but managed by the state. ${ }^{14}$ The High Court sentence supported the pathways and lock-ins of existing institutions. Most likely, the best path for the Sami Parliament to explore a Sami fisheries approach within the Norwegian management system is to continue to influence the government through political means, including the professionalization of its role in the Consultation Institute. One goal could be - with reference to the Reindeer Husbandry Act's (2007) preamble - to make sure that cultural sustainability is included in the Marine Resource Act, in addition to ecological and economic sustainability. This could develop the path to secure cultural or normative diversity in the fisheries.

\section{Conclusion}

The Sami Parliament has been successful in becoming a partner in Norwegian fisheries governance. The Norwegian fisheries management is organised in a way where locked-in decisions make it necessary to work with and inside the system. In Scott's (1995) terminology, we can say that new norms and values must be translated into practical instruments and procedures that fit into the existing legal and administrative system. As we have described, the institutional pillars in the Norwegian fisheries system have developed over time, they are strong and well adapted to the situations they shall cope with, and the social and political environment they exist in. According to Ostrom's (1990) design principles, the Norwegian institutions have the characteristics of stable and robust institutions that are resistant and difficult to transform or destroy. However, the stability and strength also restrict the space for alternative solutions. Change imposed from outside may fail because the lock-ins work as a defense against change. Therefore, change must be incremental and requires ability to work with the system, not against it.

Normatively, cognitively and regulatory, Sami interests are accounted for in the Norwegian fisheries governance system. Today, the Sami Parliament is an institutionalised part of the system that must be heard in all cases pertaining to the Sami. Successes have been realised along the institutional pathway where the Sami Parliament has worked as a partner within the system. On the other hand, despite established territorial rights, it has not been possible to gain recognition of historical Sami fishing rights for the Sami population as a whole. There are several reasons for this state of affairs. First, the question about rights is not a legal and a technical question, but a political one. It will require a political change - not only in the country as a whole, but also among the coastal people in

\footnotetext{
${ }^{14}$ Reference to the High Court Sentence: HR-2013-2200-P.
} 
the Sami administrative area. The main targeted group for a Sami fishing policy, the fjord fishers, are a mixed group, who do not all support the idea of securing local fishing rights on an ethnic basis (Søreng 2013). Rights on an ethnic basis will represent a break with traditional perception of all fishers as equals. Second, despite of the political focus on individual profitability, in terms of securing a material basis for Sami culture, a concern for the smaller vessels is embedded in the quota system and accounted for in the practical regulations (footnote 2 ). Today, smaller boats also have a relatively larger share of the catch per quota factor than bigger boats. Finally, the territorial regime of the FFB actually protects small-scale fisheries from competition from bigger boats. Hence, some of the material concerns of the Sami are part of the general fisheries policy. The FFB is a local advisory body that, even while lacking executive power, has the potential to exert considerable influence (Johnsen 2017). The strong corporative, institutionalist tradition of Norway is based on consultative partnerships of this kind and with stakeholder organisations (Jentoft and Johnsen 2015). Today, the FFB lack sufficient resources to attend to its mandate properly. In a situation where it is difficult to argue for increased Sami rights from a legal standpoint, a pragmatic approach to strengthen the FFB may yield more results. A stronger FFB may be the vehicle for securing fishing areas for the smaller vessels, while political manoeuvres to secure decent amounts of fish to the open group fishery in general and in the Sami area in particular may be more effective than a political struggle for ethnic rights. This may in practice result in a more or less free small-scale fishery in the fjords and be much less controversial, since it does not require any distinction among fishers. It would also be in line with the way the system actually works, and it will not cause institutional shocks and trigger resistance. Instead the Sami interests can work along political lines and contribute to incremental changes that over time may result in the achievement of higher goals. 


\section{References}

Angell, Elisabeth. 2004. Kjønn og etnisitet i fiskeripolitikken. En analyse av kvinners rolle i samisk fiskeripolitikk og Sametingets posisjon i norske fiskerireguleringer [Gender and ethnicity in fisheries policy. An examination of women's role in Sami fisheries policy and the position of the Sami Parliament in Norwegian fisheries regulations]. Norut NIBR-Finnmark-rapport 2004-4.

Brattland, Camilla. 2010. Mapping rights in coastal Sami seascapes. Arctic Review of Law and Politics 1 (1): 28-53.

Brattland, Camilla. 2012. Making Sami seascapes matter: Ethno-ecological governance in coastal Norway. PhD thesis. Troms $\varnothing$ : University of Troms $\varnothing$ - The Arctic University of Norway.

Buanes, Arild, Svein Jentoft, Geir Runar Karlsen, Anita Maurstad, and Siri Søreng. 2004. In whose interest? An exploratory analysis of stakeholders in Norwegian coastal zone planning. Ocean \& Coastal Management 47 (5-6): 207-223.

Davis, Anthony and Svein Jentoft. 2001. The challenge and promise of indigenous peoples' fishing rights - From dependency to agency. Marine Policy 25 (23): 223-237.

Eidheim, Harald. 1971. Aspects of the Lappish minority situation. Oslo, Bergen, Tromsø: Universitetsforlaget.

Eythórsson, Einar. 1999. Hvem skal forvalte ressursene? Forvaltning og rettigheter i fjordområdene i Nord-Norge [Who shall manage the resources? Management and rights in the fjord areas in North Norway]. In Norsk ressursforvaltning og samiske rettighetsforhold. Om statlig styring, allmenningens tragedie og lokale sedvaner i Sapmi [Norwegian resource management and Sami's jurisdiction. About national regulations, the tragedy of the commons, and local customs in Sapmi], ed. Ivar Bjørklund, 29-51, Ad Notam Gyldendal.

Eythórsson, Einar. 2008. Sjøsamene og kampen om fiskeressursene [The Coastal Sami and the battle for the fish resources]. Karasjok: Čálliid Lágádus.

Eythórsson, Einar and Stein R. Mathisen. 1998. Ressursforvaltning og lokal kunnskap i kystsamiske områder [Resource management and local knowledge in coastal Sami areas]. In Fjordressurser og reguleringspolitikk. En utfordring for kystkommuner? [Fjord resources and regulation politics. A challenge for the municipalities?], ed. Bjørn Sagdahl, 40-55, Oslo: Kommuneforlaget.

Fiskeridepartementet. 2003. Faktaark [Fact Sheets] Ressurs- og havavdelingen 2003-2004. https://www.regjeringen.no/globalassets/upload/kilde/fid/bro/2003/0001/ddd/pdfv/193378faktaark_2003_-2004.pdf, accessed 30 May 2018.

Hoel, Alf Håkon, Svein Jentoft and Knut H. Mikalsen. 1996. User-group participation in Norwegian fisheries management. In Fisheries Resource Utilization and Policy. Proceedings of the World Fisheries Congress 1993, ed. R. Meyer, C. Zhang, M. Windsor, B. McCay, L. Hushak and R. Muth. New Delhi: Oxford \& IBH Publishing CO PVT LTD.

Holm, Petter. 1995. The Dynamics of Institutionalization: Transformation Processes in Norwegian Fisheries. Administrative Science Quarterly, 40 (3): 398-422.

Holm, Petter. 1996. Fisheries Management and the Domestication of Nature. Sociologia Ruralis 36 (2): 177-188.

Jentoft, Svein. 1989. Fisheries co-management: Delegating government responsibility to fishermen's organizations. Marine Policy 13(2): 137-154. 
Jentoft, Svein. 1998. Allmenningens komedie. Medforvaltning i fiskeri og reindrift [The comedy of the commons. Co-management in fisheries and reindeer husbandry]. Oslo: Ad Notam Gyldendal.

Jentoft, Svein. 2000. The community: A missing link of fisheries management. Marine Policy 24 (1): 53-60.

Jentoft, Svein. 2004. Institutions in fisheries: What they are, what they do, and how they change. Marine Policy 28 (2): 137-149.

Jentoft, Svein. 2006. Beyond fisheries management: The Phronetic dimension. Marine Policy 30 (6): 671-680.

Jentoft, Svein. 2013. Governing tenure in Norwegian and Sami small-scale fisheries. From common pool to common property? Land Tenure 1: 91-115.

Jentoft, Svein and Camilla Brattland. 2011. Mot en samisk fiskeriforvaltning [Toward a Sami fisheries management]. In Hvor går Nord-Norge. Tidsbilder fra en landsdel i forandring [Where is North Norway heading? Pictures of the period from a region in change], ed. Svein, Jentoft, Jens-Ivar Nergård and Kjell Arne Røvik. Stamsund: Orkana Akademisk.

Jentoft, Svein and Jahn Petter Johnsen. 2015. The Dynamics of Small-Scale Fisheries in Norway: From Adaptamentality to Governability. In Interactive governance for small-scale fisheries: Global reflections, ed. Svein Jentoft and Ratana Chuenpagdee, 705-723. Cham: Springer International Publishing.

Jentoft, Svein and Geir Runar Karlsen. 1997. Sami fisheries, quota management and the right issue. In Proceedings from a seminar held in Vestman Island in May 1996, ed. Gisli Pálsson and Gudrún Pétursdóttir. TemaNord 1997: 593.

Jentoft, Svein and Trond Kristoffersen.1989. Fishermen's co-management: The case of the Lofoten Fishery. Human Organization 84 (4): 355-365.

Jentoft, Svein, Bonnie McCay and Douglas C. Wilson. 1998. Social theory and fisheries comanagement. Marine Policy 22 (4-5): 423-436.

Jentoft, Svein and Knut H. Mikalsen. 2014. Do national resources have to be centrally managed? Vested interests and institutional reform in Norwegian fisheries governance. Maritime Studies. https://doi.org/10.1186/2212-9790-13-5

Jentoft, Svein and Siri Ulfsdatter Søreng. 2017. Securing sustainable Sami small-scale fisheries in Norway: Implementing the Guidelines. In The small-scale fisheries guidelines, ed. Svein Jentoft, Ratana Chuenpagde, María José Barragán-Paladines and Nicole Franz, 277-289, MARE Publication Series 14. doi: 10.1007/978-3-319-55074-9_13

Johnsen, Jahn Petter. 2014. Is fisheries governance possible? Fish and Fisheries. doi: 10.1111/faf.12024

Johnsen, Jahn Petter. 2017. Creating political spaces at sea - Governmentalisation and governability in Norwegian fisheries. Maritime Studies. doi: 10.1186/s40152-017-0071-7

Johnsen, Jahn Petter and Svein Jentoft. 2018. Transferable quotas in Norwegian fisheries. In Fisheries, quota management and quota transfer: Rationalization through bio-economics, ed. Gordon M. Winder, 121-139. Cham: Springer International Publishing.

Josefsen, Eva. 2014. Selvbestemmelse og samstyring: En studie av Sametingets plass i politiske prosesser i Norge [Self-determination and co-governing: A study of the Sami Parliament's place in political processes in Norway]. PhD thesis. Troms $\varnothing$ : University of Troms $\varnothing-$ The Arctic University of Norway. 
Kooiman, Jan and Jentoft, Sven. 2009. Meta-governance: Values, norms and principles, and the making of hard choices. Public Administration. 87 (4): 818-836.

Kooiman, Jan, Maarten Bavinck, Svein Jentoft and Roger Pullin (eds.) 2005. Fish for life - Interactive governance for fisheries, Amsterdam: Amsterdam University Press.

Minde, Henry. 2005. Assimilation of the Sami - Implementation and consequences. Aboriginal Policy Research Consortium International (APRCi). Paper 196. http://ir.lib.uwo.ca/aprci/196

Mitchell, Ronald K., Bradley R. Agle and Donna J. Wood. 1997. Toward a theory of stakeholder identification: Defining the principle of who and what really counts. Academy of Management Review 22 (4): 853-886.

Nielsen, Kåre Nolde and Petter Holm. 2008. The TAC-Machine: On the institutionalization of sustainable fisheries resource management. In SciencelPolitics: Boundary construction in mandated science the case of ICES' advice on fisheries management. Troms $\varnothing$ : University of Troms $\varnothing$.

Norwegian National Human Rights Institution. 2016. Sjøsamenes rett til sjøfiske [The coastal Sami's rights to fish in the saltwater]. Temarapport.

Norwegian National Human Rights Institution. 2017. Årsmelding [Annual Report] 2017. Dokument 6 (2017-2018).

NOU (Norwegian Official Report). 2005. NOU 2005:10. Lov om forvaltning av viltlevende marine ressurser. Havressursloven. [The Marine Resources Act]. Statens forvaltningstjeneste.

NOU (Norwegian Official Report). 2008. NOU 2008:5 Retten til å fiske i havet utenfor Finnmark [The right to fish in the sea outside Finnmark]. Oslo: Departementenes servicesenter. Informasjonsforvaltning.

Nygaard, Vigdis and Sigrid Skålnes. (2007). Evaluering av tilskuddsordningen for Samisk utviklingsfond [Evaluation of the grant scheme for Sami Development Fund]. Norut Alta - Áltá 2007:7.

Ostrom, Elinor. 1990. Governing the commons: the evolution of institutions for collective action. Cambridge: Cambridge University Press

Paine, Robert. 1957. Coast Lapp Society. Vol 1. Oslo: Universitetsforlaget.

Paine, Robert. 1965. Coast Lapp Society. Vol 2. Oslo: Universitetsforlaget.

Pedersen, Paul, Asle Høgmo and John Trygve Solbakk. 2012. Sápmi slår tilbake: Samiske revitaliserings- og moderniseringsprosesser i siste generasjon [Sápmi Strikes Back: Sámi revitalising and modernising processes in the Last generation]. Kárášjohka: ČálliidLágádus.

Proposition to the Parliament. 2007-2008. nr. 20. Om lov om forvaltning av viltlevande marine ressursar. Det kongelige fiskeri- og kystdepartementet.

Proposition to the Parliament. 2011-2012. Prop. 70L. Endringar i deltakarloven, havressurslova og finnmarksloven.

Reguleringsrådet (The Advisory Council. 1989. Minutes from the Advisory Council 20. - 21. September and 12. October 1989. Fisheries Directorate.

Ressursfordelingsutvalget (Resource Allocation Committee) 2007. Report from the Resource Allocation Committee in The Norwegian Fishermen's Associtation. Trondheim.

Sametinget. 1998. Sak. 30/98 Handlingsplan for samiske kyst- og fjordområder 1997-2000 [Action Plan for Sami coastal and fjord areas 1997-2000]. Sámediggi/Sametinget. 
Sametinget. 2004. Sametingets melding om fiske som næring og kultur i kyst-og fjordområdene [The Sámi Parliament's report about fishing as an industry and culture in the coastal and fjord areas]. Sámediggi/Sametinget.

Sametinget. 2011. Møtebok [Meeting Book] 003/11. Sametingets plenum. Sámediggi/Sametinget.

Scott, W. Richard 1995. Institutions and organizations. London: Sage Publications.

Selznick, Philip. 2003. 'Law in Context' Revisted, Journal of Law and Society. 30: 177-86.

Smith, Carsten. 1990. Om Samenes rett til naturressurser - særlig fiskereguleringer [Sami's right to to natural resources - especially fishing regulations]. Lov og rett 1990: 507-534.

Søreng, Siri Ulfsdatter. 2007. Fishing rights struggles in Norway - Political or legal strategies? Journal of Legal Pluralism and Unofficial Law 39 (55): 187-211.

Søreng, Siri Ulfsdatter. 2008. Fishing rights discourses in Norway: Indigenous versus non-indigenous voices. Maritime Studies 6 (2): 77-99.

Søreng, Siri Ulfsdatter. 2013. Legal pluralism in Norwegian inshore fisheries: perceptions on Sami fishing rights. Maritime studies 12:9. doi: 10.1186/2212-9790-12-9

St. meld. nr. 58. 1991-1992. Om struktur og reguleringspolitikk overfor fiskeflåten (Strukturmeldingen) [White Paper to the Parliament about a structure and management policy for the fishing fleet]. Oslo: Ministry of Fisheries. 